\title{
INDUSTRIAL LOCATION IN THE TENNESSEE-TOMBIGBEE CORRIDOR
}

\author{
Robert A. Bohm, Henry W. Herzog, Jr., and Alan M. Schlottmann*
}

\section{Introduction}

The Tennessee-Tombigbee Corridor spans four states and includes fifty-one counties stretching from Mobile, Alabama, to Paducah, Kentucky (see Figure 1). The impetus for defining a region such as the Corridor is two-fold: (1) the obvious fact that the Corridor lies generally along the route of the U.S. Army Corps of Engineers Tennessee-Tombigbee Waterway Project, and (2) the desire of the Corps of Engineers, state and local officials, and planners to design and execute a consistent economic development strategy in conjunction with the actual construction of the waterway. This paper presents one element of such a development strategy. ${ }^{1}$ Our objective is to identify manufacturing industries for which the Corridor possesses a high degree of locational advantage as a future production site. In this first section, we seek to briefly describe our methodology and to outline the remainder of the paper.

Within the manufacturing sector, our methodology has three steps: (1) to develop a general gravity-potential type industrial location model which permits an unconstrained ranking of industries on the basis of potential profitability for each Corridor County, (2) to constrain the selection process on the basis of three "industrial development strategies," and (3) to permit modification of the selection process in the field on the basis of a matching of industry and county characteristics. The first step allows the pure economics of each industry to come to the fore with the 452 four-digit manufacturing industries ranked on the basis of attraction to each county. This ranking is based upon firm profitability and how this profitability is related to geographic location. County proximity to both major input suppliers and to major industrial and commercial buyers is an impor- tant determinant of this rank. In addition, county-level wage rates help determine rank for each industry in each county.

For each Corridor county, this ranking of industries by prospective profitability is quite important in that industries at the top of each list (with relatively high expected profits in the county) will require fewer inducements than industries at the bottom of each list (with relatively low prospective profits). This ranking also indicates the ordering of industries on the basis of probable relocation to the county (in absence of any inducements).

The second step of our methodology permits the introduction of an industrial development policy objective. In this paper, we have selected three development strategies:

\section{The High Wage Strategy}

2. The Regional Market Potential Strategy

3. The Employment Growth Strategy

Based on these strategies, industries are selected for each county from the rankings developed in step one. Finally, step three builds "hands on" flexibility into the entire system. Local officials can modify rankings based on existing data on industry location preferences and county resources or on the basis of new data as they become available.

The remainder of this paper is divided into four sections. First, we discuss our industrial location model in some detail. This is followed by a presentation of our three development strategies and some results of the ranking process. The next section briefly describes the supplementary data our system provides the local planner. ${ }^{2}$ Finally, the last section of this paper contains suggestions for refinements and extensions of our work.

*The University of Tennessee, Knoxville. 


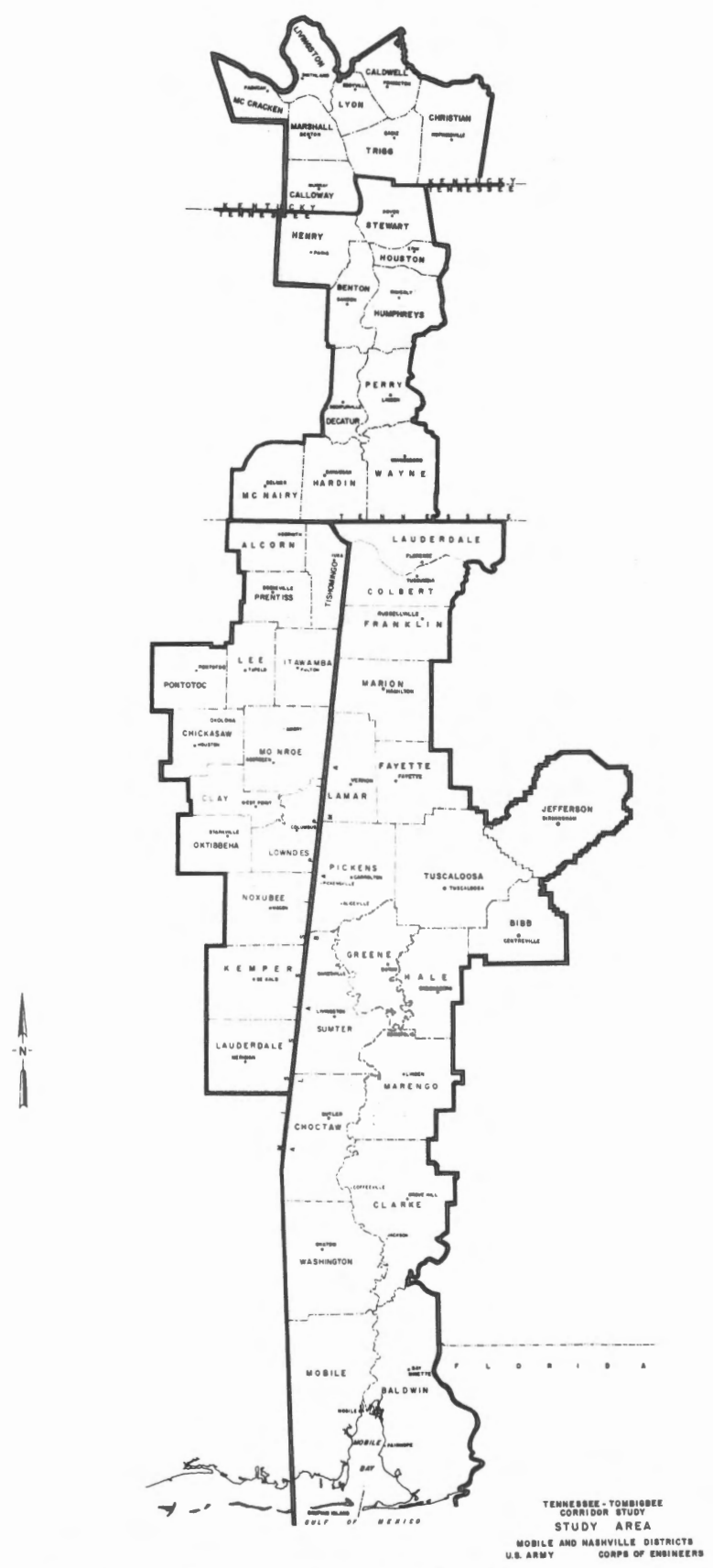

Figure 1. The Tennessee Tombigbee Corridor

\section{Methodology for Industry Rank by County}

Manufacturing location reflects a rather complex interactive process between specific industry requirements and individual county characteristics. To formally model all the determinants of this complex location process is, perhaps, impossible. However, a regional location model incorporating major elements of industrial location theory can provide a useful meth- odological tool for investigating industry location potential at the county level..$^{3}$ In this respect, our methodology views firm location as a process of profit maximization across space where industry access to both markets and materials is critical. The model is a straightforward application of the gravity and potential concepts of regional economics. ${ }^{4}$

The attractiveness potential $\left(\mathbf{A}_{\mathrm{ij}}\right)$ of a specific four-digit industry, $i$, in a specific county, $j$, is the sum of two components, access to markets and access to materials:

$$
\mathrm{A}_{\mathrm{ij}}=\begin{aligned}
& \text { Market Access (Demand Factors) + } \\
& \text { Materials Access (Supply Factors) }
\end{aligned}
$$

Each of these components will be discussed in turn. In order to minimize notation, we will assume that the analysis is for a specific industry and a given county.

\section{Market Access (Demand Factors)}

The market access term includes factors affecting industry location which are associated with demand for an industry's output. These factors include not only final demand by consumers and others but also demand by other industries to satisfy their materials requirements (often termed intermediate demand). In this respect, the market access term is given by the expression:

$R\left[r_{1}\right.$ (Final Demand Potential) $+\mathbf{r}_{2} \sum_{m} \mathbf{r}_{2 m}^{\prime}$ (Intermediate Demand Potential ${ }_{m}$ )]

where:

$$
\begin{aligned}
& \text { (a) } r_{1}+r_{2}=1 \\
& \text { (b) } \sum_{m} r_{2 m}^{\prime}=1
\end{aligned}
$$

Each component of the market access term will be discussed in turn.

The term $R$ represents the relative importance to an industry of location near its markets (as contrasted to location near its materials sources). $R$ is a proportion between zero and one. The proportion for each industry was determined by the number of market oriented responses (relative to total responses) from a survey investigating the determinants of industry location. ${ }^{5}$ The extent of market orientation can vary among manufacturing industries. For example, industries such as typesetting (SIC 2791) and photoengraving (SIC 2792) are relatively market oriented compared to textiles and apparel (for example, SIC 2261 and SIC 2361).

The proportion of an industry's output sold to 
final demand sectors is represented in the model by $r_{1}$. Major final demand sectors are consumer purchases through the wholesale and retail trade sectors, exports, and government purchases (federal, state, and local). The importance of final demand in the distribution of an industry's output can vary significantly across the manufacturing sector. For example, industries producing furniture (for example, SIC 2519 and SIC 2521) sell the majority of their output to final demand. By contrast, manufacturing industries producing primary metals (for example, SIC 3334) or wood containers-pallets (for example, SIC 2448) sell only small amounts directly to final demand sectors.

\section{Final Demand Potential}

For a specific county, this term reflects market accessibility for an industry utilizing a gravity-potential approach. In this study, final demand potentials (FDP) were computed as:

where:

$$
\mathrm{FDP}_{\mathrm{ij}}=\sum_{\mathbf{k}}\left(\mathrm{POP}_{\mathbf{k}} / \mathrm{D}_{\mathrm{j} \mathbf{k}}^{\lambda_{\mathrm{i}}}\right)
$$

$$
\begin{aligned}
\mathrm{FDP}_{\mathrm{ij}}= & \text { final demand potential for indus- } \\
& \text { try i's product in county j. } \\
\text { POP }_{\mathrm{k}}= & \text { population of the kth market area. } \\
& \text { In this study, market areas are } \\
& \text { represented by the } 48 \text { contiguous } \\
& \text { states plus the District of } \\
& \text { Columbia. } \\
= & \text { the distance between county j and } \\
& \text { market } \mathrm{k} \text {, measured by the dis- } \\
& \text { tance between a given county and } \\
& \text { the population centroid of a state. } \\
= & \text { distance decay coefficient which } \\
& \text { varies with the good being } \\
& \text { shipped. Thus, the effect of dis- } \\
& \text { tance on market accessibility var- } \\
& \text { ies with major commodity } \\
& \text { classifications and is not uniform } \\
& \text { across manufacturing industries. }
\end{aligned}
$$

Each such potential is entered as a relative (divided by the average potential computed across all counties) so that potentials greater than one imply greater than average final demand potential. Further, in order to include current population trends in the model, the estimates of population $\left(\mathrm{POP}_{\mathrm{k}}\right)$ are based on the 1985 forecasts of the MULTIREGION system. ${ }^{7}$

The proportion of industry output sold to intermediate demand is represented in the model by $r_{2}$. Intermediate demand by other manufacturing industries (and construction sectors) can represent the major distribution of a given industry's output. For example, industries such as sawmills and planing mills (SIC 2421) sell the majority of their annual output to intermediate demand. By contrast, manufacturing industries such as mattresses and bedsprings (SIC 2515) sell only minor amounts to intermediate demand sectors.

For a specific industry, the model identifies the three major sectors (industries) of intermediate demand ( $m=1$ to 3 ). ${ }^{8}$ In general, the top three intermediate demand sectors account for over 90 percent of all sales to intermediate demand. The proportion of sales to each intermediate demand sector relative to total purchases by the three industries is represented by $\mathbf{r}_{2 \mathrm{~m}}^{\prime}\left(\right.$ where $\left.\sum_{\mathrm{m}} \mathbf{r}_{2 \mathrm{~m}}^{\prime}=1\right)$.

\section{Intermediate Demand Potential}

For a specific industry and county, the intermediate demand potential (IDP) for each sector of intermediate demand ( $m=1$ to 3 ) was computed as:

where:

$$
\mathrm{IDP}_{\mathrm{ijm}}=\sum_{\mathrm{k}}\left(\mathrm{EMP}_{\mathrm{km}} / \mathrm{D}_{\mathrm{jk}}^{\lambda_{\mathrm{i}}}\right)
$$

$$
\begin{aligned}
\mathrm{IDP}_{\mathrm{ijm}}= & \text { intermediate demand potential } \\
& \text { for industry i's output in county } \mathrm{j} \\
& \text { by industry } \mathrm{m} \\
\mathrm{EMP}_{\mathrm{km}}= & \text { employment in industry } \mathrm{m} \text { in the } \\
& 49 \text { market areas. }
\end{aligned}
$$

Each such potential is entered in the model as a relative (as discussed above). Further, as with population $\left(\mathrm{POP}_{\mathrm{k}}\right)$, in order to include current economic trends, the estimates of employment $\left(\mathrm{EMP}_{\mathrm{km}}\right)$ were taken from the 1985 forecasts of the MULTIREGION system.

\section{Materials Access (Supply Factors)}

The materials access term includes factors affecting industry location which are associated with an industry's input requirements. These factors include both labor costs and the accessibility to required inputs from other manufacturing industries. In this respect, the materials access term is given by the expression:

$(1-R)\left[C_{1}\right.$ WAGE $+\mathrm{C}_{2} \underset{\mathrm{n}}{\mathbf{C}_{2 \mathrm{n}}^{\prime}}$ (Intermediate Supply Potential $n$ )]

where:

(a) $\mathrm{C}_{1}+\mathrm{C}_{2}=1$

(b) $\sum_{n} \mathbf{C}_{2 n}^{\prime}=1$

Each component of the materials access term will be discussed in turn. 


\section{(1-R)}

This term represents the relative importance to an industry of location near its materials sources. The proportion representing materials orientation has a value between zero and one. Similar to the computation of $\mathrm{R}$ discussed above, this proportion is based on industry survey data. ${ }^{9}$ The importance of materials orientation can vary among manufacturing industries. For example, industries such as hardwood veneer and plywood (SIC 2435) are relatively materials oriented compared to industries such as soap and other detergents (SIC 2841).

$C_{1}$

The proportion of labor costs to an industry's total production costs (payroll costs plus materials costs) is represented in the model by $\mathrm{C}_{1}$. This proportion is specific to each four-digit industry and associated data was available for 1979.

\section{Wage}

For each county, the wage term represents the average annual manufacturing wage (in 1979). The average county manufacturing wage is entered as a relative (divided by the average national manufacturing wage). Further, in order for relatively low manufacturing wages in a county to reflect potentially low labor costs for a prospective industry (and thus to increase the value of the materials access term), the wage is entered in the model as an inverse.

$C_{2}$

This term represents the proportion of materials costs to an industry's total production costs (payroll costs plus materials costs). This proportion is specific to each four-digit industry, and associated data was available for 1979.

\section{$C_{2 \mathrm{n}}^{\prime}$}

For a specific industry, the model identifies the three major sources (industries) of materials purchases $(n=1$ to 3$) .{ }^{10}$ In general, the top three suppliers to an industry account for over 92 percent of materials purchases. The proportion of purchased material from each of the intermediate supply sectors relative to total purchases from the three industries is represented by $C_{2 n}^{\prime}\left(\right.$ where $\left.{ }_{n}^{\Sigma} C_{2 n}^{\prime}=1\right)$.

\section{Intermediate Supply Potential}

For a specific industry and county, the intermediate supply potential (ISP) for each sector of intermediate supply ( $n=1$ to 3 ) was computed as:

where:

$$
\operatorname{ISP}_{i j n}=\sum_{k}\left(\operatorname{EMP}_{k n} / D_{j k}^{\lambda_{n}}\right)
$$

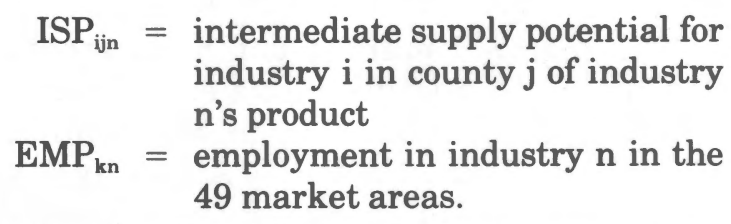

Each such potential is entered in the model as a relative and based on the 1985 forecasts of the MULTIREGION system (as discussed above).

An $A_{i j}$ can be computed for each industry for each county in the Tennessee-Tombigbee Corridor. For each county, therefore, a ranking of all four-digit industries can be made based on relative potential profitability. Industries with a high rank for a given county should have an economic locational preference for that county, assuming: (1) total demand for the industry's product cannot be met at more preferable locations elsewhere, and (2) incentives or other nonmarket factors have not been employed to alter this ranking.

\section{Development Strategies}

Three growth strategies have been developed for each county in the Tennessee-Tombigbee Corridor. As previously noted, these are: (1) a high wage strategy, (2) a regional market potential strategy, and (3) an employment growth strategy.

\section{High Wage Strategy}

An often stated goal of regional development is the attraction of "high wage" industries, i.e., firms paying wages in excess of prevailing regional wages. At the present time the wage paid by many industries within the Corridor (particularly textiles, apparel and wood products) is often only 50 or 60 percent of the average U.S. manufacturing wage. Thus, the high wage strategy for each county seeks as a development goal the attraction of manufacturing industries paying wages no less than 75 percent of the average U.S. manufacturing wage (measured as of 1979).

From the industrial location model that ranks manufacturing industries in each county 
by profitability, and thus also by ease of attraction, the twenty industries of highest rank that also satisfy the above high wage criterion are selected for each county. The twenty industries selected for Lee County, MS are shown in Table 1.

\section{Regional Market Potential Strategy \\ The regional market potential strategy focuses on the relative import-export status of manufacturing production in the Southeast. Based upon Tennessee Valley Authority (TVA) industrial market studies for the Southeast}

TABLE 1.

Industries Ranked by Growth Strategy for Lee County, MS

$\begin{array}{cl}\text { High Wage Strategy } \\ \text { SIC } & \text { INDUSTRY } \\ \text { CODE } & \text { NAME } \\ 2396 & \text { Auto Apparel Trimmings } \\ 3544 & \text { Special Dies Tools } \\ 3765 & \text { Space Vehicle Equipment } \\ 3811 & \text { Engineering Scientific Inst } \\ 3764 & \text { Space Propulsion Units } \\ 3662 & \text { Radio TV Comm Equip } \\ 3829 & \text { Meas Controlling Dev Nec } \\ 3565 & \text { Industrial Patterns } \\ 3599 & \text { Machinery Exc Elec Nec } \\ 3592 & \text { Carburetors Pistons } \\ 2753 & \text { Engraving Plate Printing } \\ 3822 & \text { Environmental Controls } \\ 2261 & \text { Finishing Plants Cotton } \\ 3825 & \text { Instr for Meas Electricity } \\ 2371 & \text { Fur Goods } \\ 3953 & \text { Marketing Devices } \\ 2291 & \text { Felt Goods } \\ 3674 & \text { Semiconductors } \\ 3823 & \text { Process Control Inst } \\ 3728 & \text { Aircraft Equipment Nec } \\ \text { Regional Market Potential Strategy } \\ \text { SIC } & \text { INDUSTRY } \\ \text { CODE } & \text { NAME } \\ 2335 & \text { Women Dresses } \\ 2385 & \text { Waterproof Outergarments } \\ 2323 & \text { Men Neckwear } \\ 2396 & \text { Auto Apparel Trimmings } \\ 3149 & \text { Footwear Exc Rubber } \\ 3544 & \text { Special Dies Tools } \\ 3811 & \text { Engineering Scientific Inst } \\ 3142 & \text { House Slippers } \\ 3171 & \text { Women Handbags Purses } \\ 3829 & \text { Meas Controlling Dev Nec } \\ 3161 & \text { Luggage } \\ 3676 & \text { Electronic Resistors } \\ 3822 & \text { Environmental Controls } \\ 3825 & \text { Instr For Meas Electricity } \\ 2429 & \text { Special Prod Sawmills } \\ 3674 & \text { Semiconductors } \\ 3823 & \text { Process Control Inst } \\ 3672 & \text { Cathode Ray Television Tubes } \\ 3151 & \text { Leather Gloves Mittens } \\ 3824 & \text { Fluid Meters Counting Dev }\end{array}$

TABLE 1. Continued

\begin{tabular}{cl}
\hline Employment Growth Strategy \\
SIC & INDUSTRY \\
CODE & NAME \\
2397 & Schiffl Embroideries \\
2389 & Apparel Accessories \\
2329 & Men Clothing \\
2352 & Hats Caps \\
2254 & Knit Underwear Mills \\
2331 & Women Blouses \\
2369 & Girls Outerwear \\
2339 & Women Outerwear \\
2384 & Robes Dressing Gowns \\
2434 & Wood Kitchen Cabinets \\
2328 & Men Work Clothing \\
2394 & Canvas Related Prods \\
2395 & Pleating Stitching \\
2396 & Auto Apparel Trimmings \\
3544 & Special Dies Tools \\
3811 & Engineering Scientific Inst \\
3662 & Radio TV Comm Equip \\
3829 & Meas Controlling Dev Nec \\
3599 & Machinery Exc Elec Nec \\
3161 & Luggage \\
\hline
\end{tabular}

(conducted from 1976 to the present), a manufacturing industry classified as "import" represents an industry whose product demand in the Southeast exceeds local production. By contrast, a manufacturing industry classified as "export" represents an industry whose product demand in the Southeast is less than local production. These market analyses can provide useful information for each industry on the size of local markets relative to current levels of local production. The regional market potential strategy selects only manufacturing industries whose product demand in the Southeast exceeds local production. The first twenty industries selected for Lee County, MS are shown in Table 1.

\section{Employment Growth Strategy}

The employment growth strategy focuses on industries with significant past employment growth in the U.S. Based upon the growth of employment between 1973 and 1978, this development strategy selects only those industries with growth either equalling or exceeding that of total manufacturing. This strategy provides a focus for local officials wishing to maximize "job" creation. The top twenty industries selected for Lee County, MS are shown in Table 1.

\section{Evaluation of Results}

Table 2 provides a listing of the four digit industry codes ranked first for each strategy 
TABLE 2.

Comparison of Strategy Rankings by Size of County

Four Digit

Industry Ranked First

\begin{tabular}{cccc}
\hline & High & Regional & Employment \\
Wage & Markets & Growth \\
County & Strategy & Strategy & Strategy \\
\hline
\end{tabular}

Group A: 1980 Population 50,000 or Greater

$\begin{array}{llll}\text { Baldwin, AL } & 3769 & 3811 & 2397 \\ \text { Colbert, AL } & 2371 & 2396 & 2371 \\ \text { Jefferson, AL } & 3271 & 3259 & 3273 \\ \text { Lauderdale, AL } & 2261 & 2335 & 2284 \\ \text { Mobile, AL } & 2911 & 2952 & 2911 \\ \text { Tuscaloosa, AL } & 2821 & 2822 & 2821 \\ \text { Christian, KY } & 2261 & 2335 & 2389 \\ \text { McCracken, KY } & 3355 & 3355 & 3355 \\ \text { Lauderdale, MS } & 2999 & 2952 & 2999 \\ \text { Lee, MS } & 2396 & 2335 & 2397 \\ \text { Lowndes, MS } & 2396 & 2335 & 2389\end{array}$

Group B: 1980 Population between 25,000 and 50,000

$\begin{array}{llll}\text { Clarke, AL } & 2396 & 2396 & 2397 \\ \text { Franklin, AL } & 2361 & 2335 & 2389 \\ \text { Marengo, AL } & 2371 & 2323 & 2371 \\ \text { Marion, AL } & 2261 & 2335 & 2389 \\ \text { Calloway, AL } & 3599 & 2335 & 2397 \\ \text { Marshall, KY } & 3355 & 3355 & 3355 \\ \text { Alcorn, MS } & 2396 & 2335 & 2397 \\ \text { Monroe, MS } & 2396 & 2335 & 2435 \\ \text { Oktibbeha, MS } & 3769 & 2335 & 2434 \\ \text { Henry, TN } & 2396 & 2335 & 2397 \\ \text { Group C: 1980 Population } & & & \\ & & & \\ \text { Bibb, AL } & & & \\ \text { Choctaw, AL } & 32,000 & 3259 & 3273 \\ \text { Fayette, AL } & 2999 & 2952 & 2999 \\ \text { Green, AL } & 2261 & 2335 & 2389 \\ \text { Hale, AL } & 2753 & 2335 & 2397 \\ \text { Lamar, AL } & 2261 & 2335 & 2389 \\ \text { Pickens, AL } & 2261 & 2335 & 2397 \\ \text { Sumter, AL } & 2261 & 2335 & 2389 \\ \text { Washington, AL } & 2371 & 2323 & 2371 \\ \text { Caldwell, KY } & 2911 & 2952 & 2911 \\ \text { Livingston, KY } & 3334 & 3334 & 3334 \\ \text { Lyon, KY } & 3599 & 3811 & 3599 \\ \text { Trigg, KY } & 3361 & 3361 & 3361 \\ \text { Chickasaw, MS } & 3322 & 3322 & 2397 \\ \text { Clay, MS } & 3811 & 2335 & 2397 \\ \text { Itawamba, MS } & 2999 & 2952 & 2999 \\ \text { Kempter, MS } & 3811 & 2335 & 2387 \\ \text { Noxubee, MS } & 2431 & 2335 & 2434 \\ \text { Pontotoc, MS } & 2753 & 2335 & 2434 \\ \text { Prentiss, MS } & 3769 & 2335 & 2397 \\ \text { Tishumingo, MS } & 3811 & 2335 & 2397 \\ \text { Benton, TN } & 3811 & 2335 & 2397 \\ \text { Decatur, TN } & 2261 & 2335 & 2397 \\ \text { Hardin, TN } & 2261 & 2335 & 2397 \\ & 2396 & 2335 & 2397\end{array}$

TABLE 2. Continued

\begin{tabular}{|c|c|c|c|}
\hline \multirow[b]{2}{*}{ County } & \multicolumn{3}{|c|}{$\begin{array}{c}\text { Four Digit } \\
\text { Industry Ranked First }\end{array}$} \\
\hline & $\begin{array}{c}\text { High } \\
\text { Wage } \\
\text { Strategy }\end{array}$ & $\begin{array}{l}\text { Regional } \\
\text { Markets } \\
\text { Strategy } \\
\end{array}$ & $\begin{array}{c}\text { Employment } \\
\text { Growth } \\
\text { Strategy }\end{array}$ \\
\hline Houston, TN & 2261 & 2335 & 2284 \\
\hline Humphreys, TN & 2262 & 2323 & 2371 \\
\hline McNairy, TN & 2396 & 2335 & 2397 \\
\hline Perry, TN & 2261 & 2335 & 2389 \\
\hline Stewart, TN & 3811 & 2335 & 2397 \\
\hline Wayne, TN & 2261 & 2335 & 2397 \\
\hline
\end{tabular}

within the entire Corridor. Although this listing does not illustrate the diversity present in each county's individual rankings, several interesting observations can be made. To facilitate this brief evaluation, we have divided the fifty-one Corridor Counties into three groups based on 1980 population (greater than 50,000 , between 25,000 and 50,000, less than 25,000).

Looking at Table 2, we offer the following comments:

1. For the small counties, the total diversity of industries identified is low when compared to the larger population groups. This result undoubtedly reflects considerable homogeneity among many of the Corridor's small rural counties.

2. Within strategies, the same industry is often identified for more than one county. As with point one, this is more characteristic in the small county cases. Note for example industry 2335 for the less than 25,000 group under the Regional Market Potential Strategy.

3. As would be expected, industries generally considered higher skill-higher wage are more prevalent in the higher population groups.

4. The number of two digit groups identified is limited. In 38 cases, the same (or the closely related Textiles 22, Apparel 23 industries) two digit industry appears for all three strategies.

5. In five cases, the same four digit industry is listed for all three strategies.

6. Several industry groups that would seem logical candidates for the Corridor, a priori, are completely absent or seldom listed (e.g., SIC 28, in particular). 


\section{Matching Industry Requirements With County Preferences and Resources}

In our system, we attempt to provide local planners with more information than the rankings presented in the previous section. This information is intended to: (1) enrich the local selection process by providing data on important industry characteristics, and (2) bring the location decision itself down from the regional economics of our model to the selection of specific sites for plant expansion. In this regard, our hypothesis is that among the set of equally profitable locations a firm will decide on a specific site on the basis of a matching of industry requirements and local resources. We wish to suggest further that this "second level" location decision is more a matter of negotiation between industry officials and local development officials than modeling.

Our system provides three types of information important to the negotiation process: (1) Selected Industry Characteristics (these data will help local officials decide on the desirability of a typical industry for their county), (2) Selected Industry Requirements (these data characterize several of each industry's input requirements), and (3) Local Characteristics (these data indicate local resources that can be matched with industry requirements). Each type of data will be discussed briefly.

\section{TVA Market Potential}

Subject to data availability, the importexport status of production in the Southeast is shown. (See Regional Market Potential Strategy above.)

\section{Percent Growth in 1980-1985}

Information on future growth prospects of U.S. manufacturing industries over the period $1980-1985$ is also tabulated. These projections, available for only a portion of the 452 four-digit manufacturing industries considered in this study, were obtained from the 1981 U.S. Industrial Outlook. ${ }^{15}$

\section{Selected Industry Requirements}

Transportation (Railway, Highway, Water).

For each manufacturing industry, we indicate the relative importance of three transportation modes (railways, highways, and water) in the distribution of industry output. For each transportation mode, the percent of output shipped by each carrier in 1977 (as a percent of total ton miles) is shown. ${ }^{16}$ This information can be used to identify the major transportation mode, or modes, for each industry.

\section{Energy (Electric, Coal Use, and Natural Gas)}

For each manufacturing industry, we indicate the relative importance of three major energy sectors: electricity, coal, and natural gas. Each energy sector is shown as a percent of total energy costs (fuels plus electricity). ${ }^{17} \mathrm{This}$ information indicates the relative importance of each energy source to each manufacturing industry.

\section{Water Use per Firm}

We also indicate the average water use per firm in each manufacturing industry (in billions of gallons per year in 1978). ${ }^{18}$

Heavy water-using, or "water-oriented," manufacturing plants may be attracted to Corridor counties adjacent to the waterway. Thus, planners concerned with industrial development throughout the region should be aware of industries exhibiting heavy water use.

\section{Selected Industry Characteristics}

\section{Regional Firms}

For each four-digit industry, information on the number of operating firms in 1979 in a surrounding multicounty region is provided. ${ }^{11}$ The existence of similar firms within a region may indicate special regional conditions which increase the likelihood of firm agglomeration.

\section{Relative Growth}

For each manufacturing industry, information on national employment growth between 1973 and 1978 is provided. This employment growth is presented in relative form (national growth in the specific four-digit industry divided by average U.S. manufacturing growth).

\section{Relative Wage}

The average (national) wage in 1979 of each manufacturing industry is also computed. The number is presented in relative form (average wage in the industry divided by the average wage paid in all manufacturing industries).

\section{TVA Recommended}

An example of another industry development study is that available from TVA. For fifteen 
Corridor counties, a "target industry" or related "industrial development analysis" conducted by the Division of Economic Development, TVA, provides a second source of information on industrial location within the Corridor. ${ }^{12}$ These studies were completed for the most part between 1978 and $1981 .{ }^{13}$

\section{EDA Recommended}

A second example of an alternative development study is that available from the Economic Development Administration (EDA). For fourteen Corridor counties, an industrial rankingcommunity/industry match conducted by the Industrial Locator Service (ILS) of the EDA was available. These analyses, conducted for the most part during 1978, provide a third source of information on industrial location within the Corridor. ${ }^{14}$

\section{County Location Characteristics}

Data are provided for seven categories of county characteristics relevant to manufacturing industry location as follows: ${ }^{19}$

\section{Transportation}

These data provide information on the local transportation system. They show distances to various types of facilities from each county as well as some indication of quality of service. The quality indexes for rail and port facilities represent simple counts of important characteristics provided by the nearest station or terminal. (For railroads these are the provision of six types of facilities: reciprocal switching, freight terminal, team track, piggy back ramp, freight house, and rail yard. For ports these indicate type of vessels served: barges, tankers, bulk carriers, general cargo, and containerized cargo.)

\section{Land Use}

These data indicate the number of industrial sites with a minimum size of 20 acres which exist in each county at the present time. The number of 20 acre sites with all utilities and various transportation services is also shown.

\section{Public Utilities}

These data indicate the availability of various public utility services in each county.

\section{Energy}

These data indicate the availability and use of various energy sources in each county.

\section{Educational Resources}

These data indicate the range of educational opportunities available within a reasonable commuting distance from each county.

\section{Public Services}

Information is provided on two locally provided public services as an indication of the relative size of the government sector in each county. For police force, the number shown is the total number of officers in the county. The industrial fire insurance rating indicates the extent of local fire protection.

\section{Local Incentives}

These data indicate the willingness of local officials to provide a climate conducive to industrial development. The availability of favorable industrial zoning, industrial development bonds and tax incentives is shown.

\section{Summary}

The objective of this paper was to describe an approach to identifying manufacturing industries for which the Tennessee-Tombigbee Corridor possesses a high degree of locational advantage as a future production site. Our methodology consisted of three steps: (1) to develop a general gravity-potential type industrial location model which permits an unconstrained ranking of industries on the basis of potential profitability for each Corridor County, (2) to constrain the selection process on the basis of three "industrial development strategies" and (3) to permit modification of the selection process in the field on the basis of a matching of industry and county characteristics.

The first step of the methodology allowed the pure economics of each manufacturing industry to come to the fore for each county. The second step permitted the introduction of an industrial development policy objective. In this report we considered three development strategies: a high wage strategy, a regional market potential strategy, and an employment growth strategy. Finally, step three built "hands on" flexibility into the entire system. Local officials can modify the rankings based on data provided in this report or on the basis of new data as it becomes available.

In addition to refinements to reflect detailed interindustry and transportation linkages, several extensions to our system would enhance its 
value as an industrial location tool. One such extension would involve an examination of additional development strategies. For instance, if local environmental resources are perceived to constrain future manufacturing development, then a pertinent strategy would examine pollutant discharges on an industryby-industry basis. A second extension to the methodology would consider the occupational requirements of alternative development strategies, and the capacity of the local work force to supply such occupations and skills. With respect to industrial recruitment, such information would inform county and development district personnel of likely skill imbalances. In addition, such information would be extremely useful for the design of technical school curricula or other approaches to upgrading local labor force skills.

A third extension would involve the integration of the Industrial Locator Service (ILS) methodology with that employed in this study. Because the ILS ranks manufacturing industries on the basis of plant needs and community characteristics, and the methodology considered in this document ranks industries by likelihood of county attraction, the two approaches are complementary and might be integrated in future work. A final methodological extension would consider the importance of international markets.

\section{FOOTNOTES}

'This paper is based upon the authors' study for the Mobile District, U.S. Army Corps of Engineers (1983). Counties were included in the study region based upon planning needs of the Corps. For a general overview of current socio-economic conditions in this region, see the above report.

${ }^{2}$ An appendix that describes this supplementary data is available upon request from the authors.

${ }^{3}$ For a review of the literature in industrial location, see Smith (1971).

${ }^{4}$ For a review of these concepts in the regional science literature, see Isard (1960).

${ }^{5}$ See U.S. Department of Commerce, Economic Development Administration (1973). Of particular interest is the section of the survey dealing with locational objectives to be achieved by the firm. Survey results at the five-digit industry level were aggregated to the four-digit level. For firms where four-digit detail was not available, an industry average across the appropriate two-digit level was used.

'The distance decay coefficient is adjusted by thirteen major commodity classifications. Our coefficients are based on the work by Black (1972).

'See Henry W. Herzog, Jr., et al. (1981).

${ }^{8}$ Based upon the input-output structure of the national economy, these sectors are identified at the two-digit level for each industry. For a discussion of the input-output data, see Ritz (1979).
${ }^{9}$ See U.S. Deprtment of Commerce, Economic Development Administration (1973). (1-R) represents the number of materials oriented responses relative to total responses.

${ }^{10}$ Based upon the input-output structure of the national economy, these sectors are identified at the two-digit level for each industry. For a discussion of the input-output data, see Ritz (1979).

"These data were compiled by the Economic Analysis and Development Branch, Tennessee Valley Authority (TVA), and made available to the authors of this study (subject to disclosure regulations). The delineation of the regions was based upon SMSA definitions and labor market areas. As noted above in footnote two, an appendix describing this information is available upon request.

${ }^{12}$ In certain cases, these studies are for a specific city within the county. For example, in this study, the target industry analysis for Columbus, Mississippi, was used to provide additional information for the county of Lowndes, Mississippi.

${ }^{13}$ The number of matches for a county is, in general, somewhat low. The target industry analyses are often restricted to meet several predetermined criteria. In past studies, these criteria include constraints related to such factors as rates of past growth (measured with respect to employment and/or value of shipments), rates of future growth (employment and/or value of shipments), location potential in the TVA area defined relative to the existence of similar industries in the area and/or the need for firms to supply existing industries, the wage level of an industry, and additional production needed to meet product demand in the Southeast. Because the industrial location model in this study is relatively unrestricted, the number of matches would be expected to be relatively low.

${ }^{14}$ The number of matches for a county is, in general, relatively low. The data base for the EDA selection of manufacturing industries includes only those manufacturing industries which had demonstrated "reasonable" growth between 1958 and 1967, or which appeared to have "good" growth prospects in 1970. Later time periods are not included. In addition, manufacturing industries not eligible to receive assistance from EDA to locate in designated depressed areas (for example, apparel manufacturers) were excluded from the data base. Thus, the number of matches with the present study would be expected to be relatively low.

${ }^{15}$ For many industries, these analyses are at a two-digit or three-digit level of industrial classification.

${ }^{16}$ The three percentages do not necessarily total 100 percent. The percent shipped by "other" transportation modes includes pipelines, air freight, and undisclosed shipments. In general, the three transportation modes identified are dominant across industries in the Census of Transportation.

${ }^{17}$ These data, for 1978, are reported in the Annual Survey of Manufacturing-Fuels and Electric Energy Consumed. The three percentages do not necessarily add to 100 percent. In general, the percentage of costs associated with "other" energy sectors represents oil use.

${ }^{18}$ This information is based upon total water usage (where reported) in the Census of Manufacturers-Water Use in Manufacturing. In general, information on water use is not collected for apparel and textile industries.

${ }^{19}$ This survey information was supplied by regional Councils of Governments and Development Districts within the corridor by employing a standard EDA/ILS questionnaire.

\section{REFERENCES}

Black, William R., "Interregional Commodity Flows: Some Experiments with the Gravity Model," Journal of Regional Science, Vol. 12, No. 1, April 1972, pp. 107-118. 
Herzog, Henry W., David J. Bjornstad and Dana M. Stuckwish, "Long-Term Projections of Population and Employment for Regions of the United States," Economic Analysis Section, Energy Division, Oak Ridge National Laboratory, ORNL/TM-7641, August 1981.

Isard, Walter, Methods of Regional Analysis: An Introduction to Regional Science, (Cambridge: The M.I.T. Press, 1960), pp. 493-568

Ritz, P., "The Input-Output Structure of the U.S. Economy,
1972," Survey of Current Business, Feb. 1979, pp. 34-72. Smith, David M., Industrial Location: An Economic Geographical Analysis, (New York: John Wiley \& Sons, Inc., 1971).

U.S. Army Corps of Engineers, Mobile District, Industrial Location in the Tennessee-Tombigbee Corridor, January 1983.

U.S. Department of Commerce, Economic Development Administration, Industrial Location Determinants, 1973. 